\title{
7.2 Проблеми та перепони активізації інноваційної діяльності в Україні
}

Легендарному американському підприємцю Стіву Джобсу належить вислів «Інновація відрізняє лідера від того, хто доганяє» [398]. 3 думкою Стіва Джобса важко не погодитися: відповідно до Global Innovation Index [399] найбільш інноваційно активними країнами є саме держави-економічні лідери Швейцарія, Швеція, США, Великобританія, Республіка Корея, Нідерланди, Фінляндія, Сінгапур, Данія, Німеччина, Франція, Китай, Японія.

Але не Україна, яка, на жаль, не належить до активних країн-інноваторів: відповідно до актуальних даних Державної служби статистики України, частка кількості промислових підприємств, що впроваджували інновації (продукцію та/або технологічні процеси), в загальній кількості промислових підприємств складає 14,9\% [400]. Що ж є причиною того, що Україна, відома своїм потужним інтелектуальним потенціалом, $\epsilon$ аутсайдером у сфері розроблення та впровадження інновацій?

Метою дослідження $\epsilon$ виявлення проблем i перепон активізації інноваційної діяльності в Україні.

Інформаційною базою дослідження оберемо статистичний збірник «Наукова та інноваційна діяльність України» [401].

На підставі дослідження трендів ключових показників інноваційної діяльності в України, виділимо наступні перепони та проблеми їі активізації.

За останнє десятиріччя кількість організацій, що здійснюють науководослідні роботи (тут і надалі - НДР), скоротилася майже на 41\% (рис. 1). 


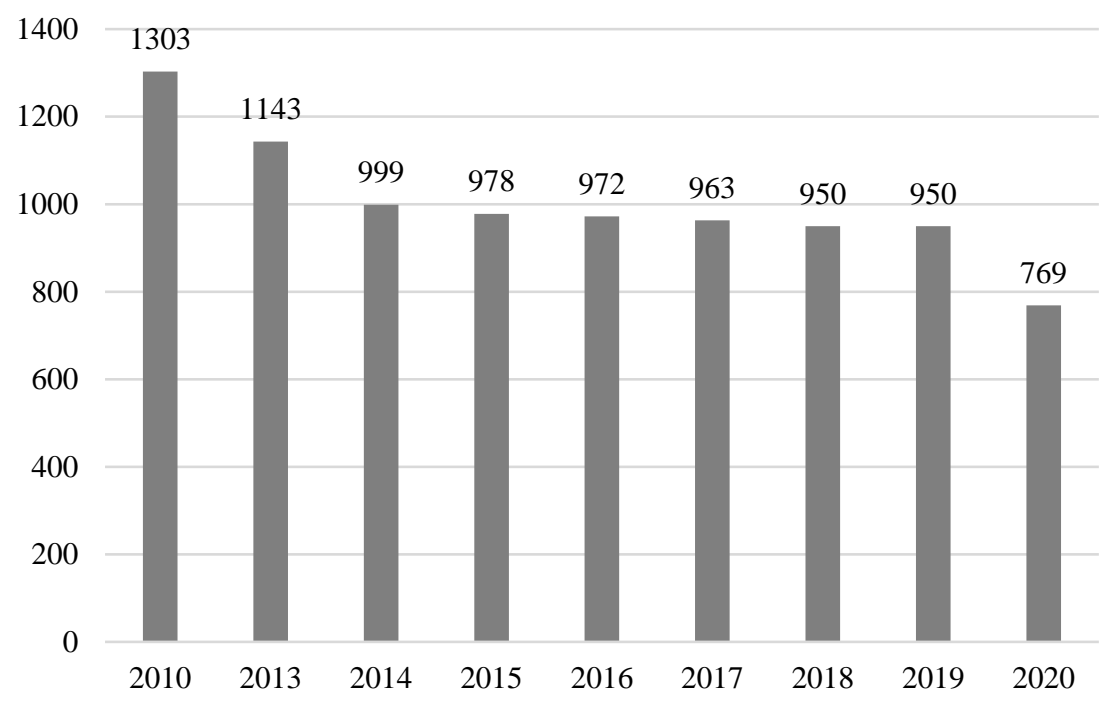

Рисунок 1. Кількість організацій, що здійснюють НДР в Україні, од. [побудовано авторами за даними [4]]

Зменшення індикатору спостерігалося у всіх регіонах України, проте найбільш разючою ця зміна була в Луганській області (-78\%), Донецькій області (-77\%), Миколаївській області (-73\%), Кіровоградській області (-60\%), Чернігівській області (-59\%), Рівненській області (-57\%), Івано-Франківській області (-56\%). Найменших змін досліджуваний показник зазнав у м. Києві ($11 \%)$, Житомирській області (-22\%), Одеській області (-25\%), Запорізькій області (-27\%). Не змінилася кількість організацій, що здійснюють НДР, лише у Хмельницькій області.

До речі, переважна більшість вітчизняних організацій-інноваторів наразі зосереджена в таких адміністративно-територіальних одиницях України як м. Київ (38\%), Харківська область (13\%), Львівська область (7\%), Одеська область (6\%) і Дніпропетровська область (5\%).

Найменше (менше $1 \%$ ) зазначених підприємств зосереджено у Хмельницькій області, Рівненській області, Кіровоградській області, Житомирській області, Волинській області.

В той же час певною мірою різняться результати аналізу динаміки цього показнику у розрізі видів економічної діяльності: закономірне зменшення спостерігається у таких видах економічної діяльності як, наприклад, «Сільське 
господарство, лісове господарство та рибне господарство», «Переробна промисловість», «Операції з нерухомим майном», «Професійна, наукова та технічна діяльність», «Охорона здоров’я та надання соціальної допомоги», «Мистецтво, спорт, розваги та відпочинок».

Тоді як спостерігається і зростання кількості інноваційно активних підприємств - в сфері телекомунікацій; діяльності у сфері адміністративного та допоміжного обслуговування; освіти.

Ще більш разючих негативних змін зазнав наступний ключовий показник аналізу інноваційної діяльності - «Кількість працівників, задіяних у виконанні НДР»-зменшення на 57\% (рис. 2).

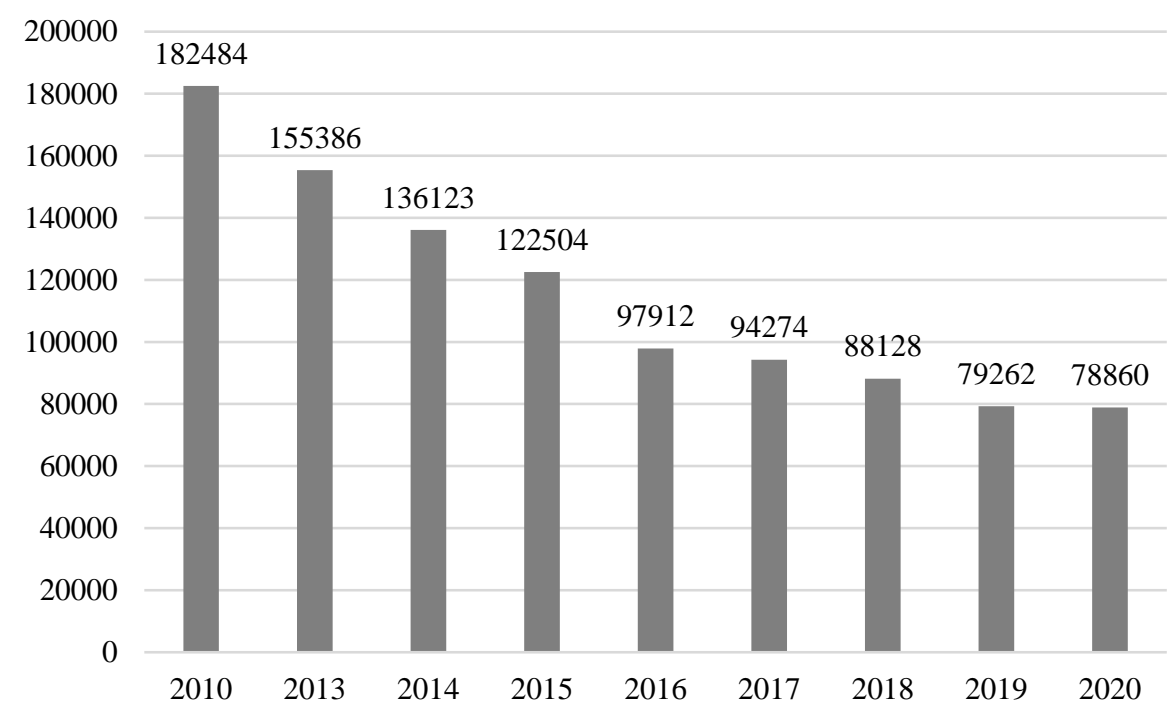

Рисунок 2. Кількість працівників, задіяних у виконанні НДР в Україні, осіб [побудовано авторами за даними [4]]

Також певну цікавість становлять ознаки суттєвої диференціації кількості працівників, задіяних у виконанні НДР в Україні, за галузями наук. 47\% таких працівників займаються дослідженнями у галузі технічних наук, 27\% природничих наук, 9\% - суспільних наук, 8\% - сільськогосподарських наук, $6 \%$ - медичних наук, 3\% - гуманітарних наук.

Але вказана структурна характеристика не зберігається у розрізі регіональної диференціації (табл. 1). 
Таблиця 1

Структурна характеристика розподілення працівників, задіяних у виконанні НДР, за галузями наук у регіональному розрізі, \% *

\begin{tabular}{|l|c|c|c|c|c|c|}
\hline \multirow{2}{*}{ Регіони } & \multicolumn{7}{|c|}{$\begin{array}{c}\text { Грилузі наук } \\
\text { науки }\end{array}$} & $\begin{array}{c}\text { технічні } \\
\text { науки }\end{array}$ & $\begin{array}{c}\text { медичні } \\
\text { науки }\end{array}$ & $\begin{array}{c}\text { сільсько- } \\
\text { господарські } \\
\text { науки }\end{array}$ & $\begin{array}{c}\text { суспільні } \\
\text { науки }\end{array}$ & $\begin{array}{c}\text { гуманітарні } \\
\text { науки }\end{array}$ \\
\hline Вінницька & 12,69 & 17,59 & 3,34 & 56,35 & 5,57 & 4,45 \\
\hline Волинська & 32,28 & 17,32 & 0,00 & 29,13 & 15,75 & 5,51 \\
\hline $\begin{array}{l}\text { Дніпро- } \\
\text { петровська }\end{array}$ & 6,04 & 85,73 & 2,54 & 4,48 & 1,09 & 0,12 \\
\hline Донецька & 33,75 & 45,51 & 8,36 & 4,33 & 6,50 & 1,55 \\
\hline Житомирська & 2,99 & 31,34 & 0,00 & 44,03 & 13,81 & 7,84 \\
\hline Закарпатська & 77,65 & 0,00 & 2,75 & 13,14 & 6,47 & 0,00 \\
\hline Запорізька & 0,99 & 90,59 & 1,95 & 4,61 & 1,76 & 0,11 \\
\hline $\begin{array}{l}\text { Івано- } \\
\text { Франківська }\end{array}$ & 21,18 & 38,65 & 7,42 & 17,69 & 5,02 & 10,04 \\
\hline Київська & 4,20 & 28,17 & 0,33 & 61,46 & 5,32 & 0,53 \\
\hline Кіровоградська & 13,64 & 32,58 & 0,00 & 33,33 & 20,45 & 0,00 \\
\hline Луганська & 29,19 & 32,54 & 17,22 & 9,09 & 11,96 & 0,00 \\
\hline Львівська & 36,49 & 33,30 & 4,93 & 7,79 & 10,01 & 7,48 \\
\hline Миколаївська & 4,46 & 82,82 & 0,00 & 3,45 & 8,02 & 1,24 \\
\hline Одеська & 42,52 & 22,88 & 11,67 & 15,19 & 7,18 & 0,56 \\
\hline Полтавська & 16,47 & 28,68 & 2,71 & 30,81 & 12,02 & 9,30 \\
\hline Рівненська & 27,66 & 44,68 & 0,00 & 27,66 & 0,00 & 0,00 \\
\hline Сумська & 19,63 & 61,15 & 3,48 & 15,75 & 0,00 & 0,00 \\
\hline Тернопільська & 38,46 & 11,76 & 21,72 & 28,05 & 0,00 & 0,00 \\
\hline Харківська & 28,65 & 47,51 & 9,19 & 7,10 & 6,70 & 0,84 \\
\hline Херсонська & 19,86 & 11,78 & 0,00 & 63,97 & 3,69 & 0,70 \\
\hline Хмельницька & 7,73 & 46,35 & 0,00 & 17,60 & 28,33 & 0,00 \\
\hline Черкаська & 34,85 & 18,40 & 0,00 & 30,95 & 9,96 & 5,84 \\
\hline Чернівецька & 53,08 & 22,64 & 1,63 & 16,67 & 5,98 & 0,00 \\
\hline Чернігівська & 17,84 & 46,47 & 0,00 & 27,84 & 2,94 & 4,90 \\
\hline м. Київ & 32,65 & 39,54 & 7,34 & 3,52 & 12,02 & 4,94 \\
\hline
\end{tabular}

* розраховано авторами за даними [401]

Як бачимо, виконанню НДР за природничою тематикою віддають перевагу науковці у Закарпатській області, Чернівецькій області, Одеській області, Львівській області, Волинській області, Тернопільській області та Черкаській області; за технічною тематикою - у Дніпропетровській області, Донецькій області, Запорізькій області, Івано-Франківській області, Луганській області, Миколаївській області, Рівненській області, Сумській області, Харківській області, Хмельницькій області, Чернігівській області та м. Києві; за сільсько- 
господарською тематикою - у Вінницькій області, Житомирській області, Київській області, Кіровоградській області, Полтавській області та Херсонській області. Відповідно, значно меншою популярністю у науковців користуються тематики НДР у галузі медичних наук, суспільних наук і гуманітарних наук.

У певному контексті до проблемних питань розвитку інноваційної діяльності в Україні можна віднести вікову структуру працівників, задіяних у виконанні НДР, з переважанням (більше 30\%) науковців похилого віку (рис. 3).

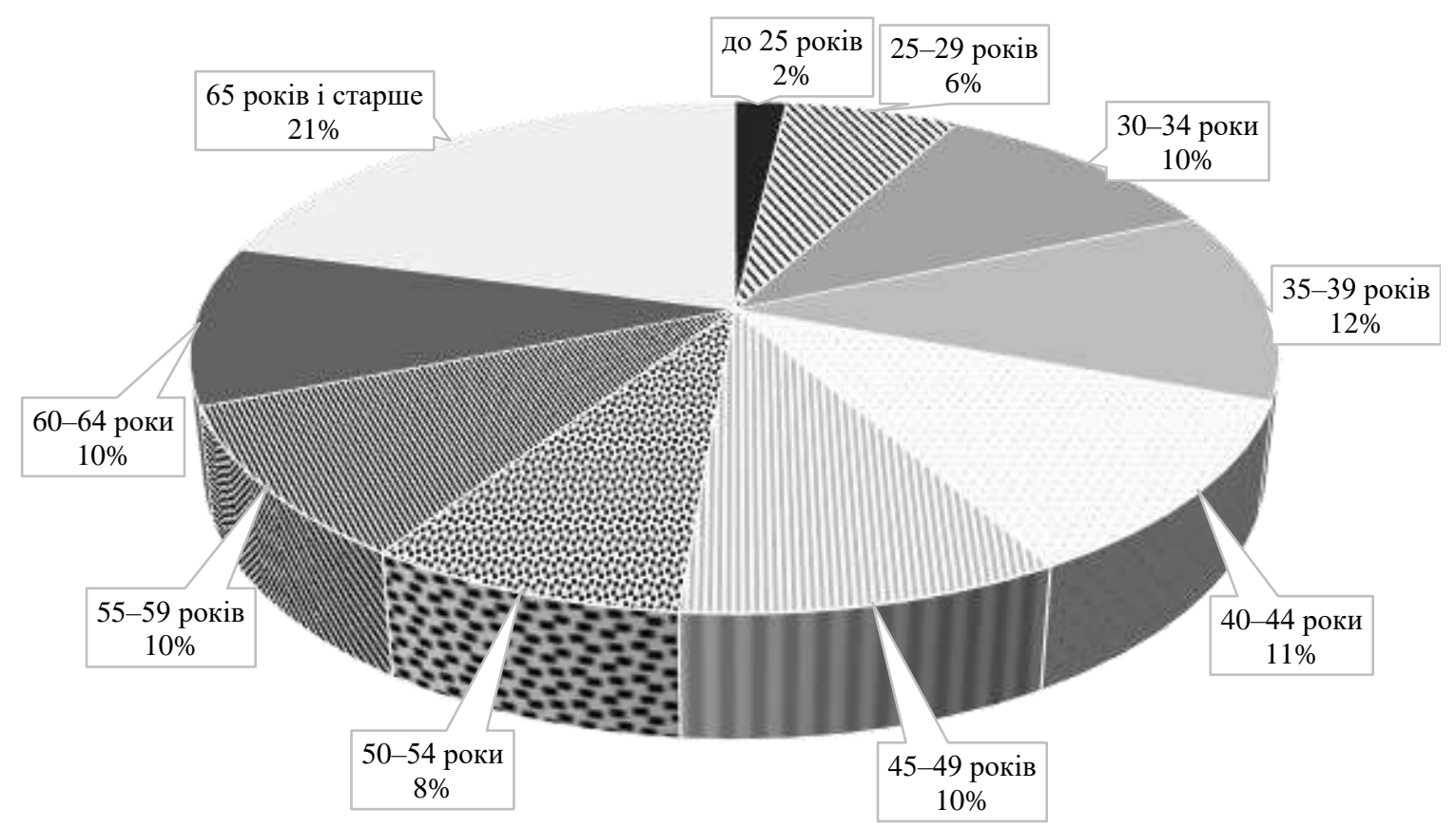

Рисунок 3. Вікова структура працівників, задіяних у виконанні НДР, \% [побудовано авторами за даними [4]]

Звичайно, однозначно ідентифікувати зазначену вікову структуру працівників, задіяних у виконанні НДР, як перепону розвитку інноваційної діяльності в Україні не слід, оскільки науковці старшого віку є безперечно більш кваліфікованими та досвідченими, мають наукові ступені та вчені/почесні звання, вітчизняні і міжнародні відзнаки. Проте й загальновідомим є той факт, що молодь $є$ більш сприйнятливою до усього нового, швидше адаптується до змін у зовнішньому середовищі та знаходить адекватну відповідь новим викликам інноваційного розвитку. 
Найчастіше до перепон інноваційному розвитку відносять брак фінансування. Дійсно, фінансовий аспект інноваційної діяльності є надзвичайно важливим. В Україні сьогодні фінансування інновацій здійснюється у більших обсягах, ніж, наприклад, десять років тому (17022419,3 тис. грн у 2020 році проти 8107057,4 тис. грн у 2010 році).

При цьому джерелами фінансування інноваційної діяльності, як правило, виступають кошти бюджету, кошти організацій державного сектору та власні кошти підприємств.

Переважно фінансування отримують науково-технічні (експериментальні) розробки. Фундаментальні дослідження та прикладні дослідження фінансуються приблизно в однаковому обсязі (рис. 4).

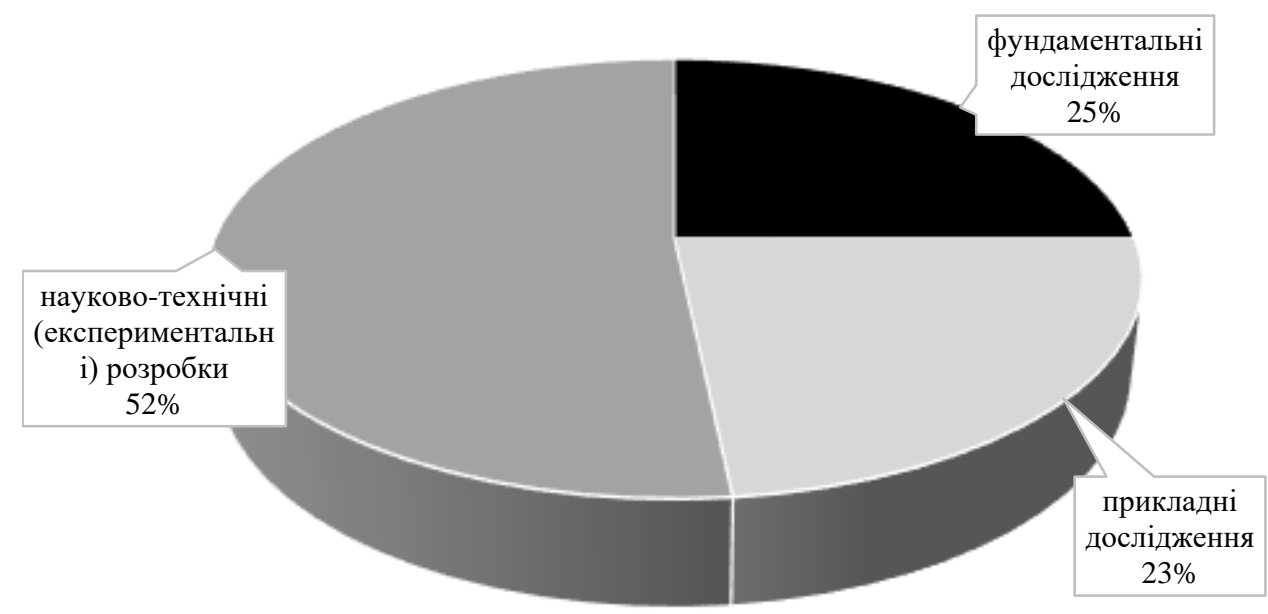

Рисунок 4. Пріоритетні напрями фінансування НДР, \% [побудовано авторами за даними [4]]

При цьому в галузі природничих наук в основному фінансуються фундаментальні дослідження; у галузі технічних наук - науково-технічні (експериментальні) розробки; у галузі медичних наук - прикладні дослідження; у галузі сільськогосподарських наук - прикладні дослідження; у галузі суспільних наук - прикладні дослідження; у галузі гуманітарних наук фундаментальні дослідження. 
У структурі витрат на інноваційну діяльність переважають капітальні витрати на інновації (69\%). Витрати на придбання послуг, матеріалів для інновацій складають близько 22\%. Відповідно, витрати на персонал, який працює над інноваціями, будуть становити 9\%.

Стрімке зменшення кількості організацій, що здійснюють НДР, та скорочення кількості працівників, задіяних у виконанні НДР, попри відносну стабільність обсягу фінансування інноваційної діяльності в Україні, закономірно призвели до зменшення частки витрат на НДР у ВВП (особливо у порівнянні 3 деякими європейськими країнами - рис. 5).

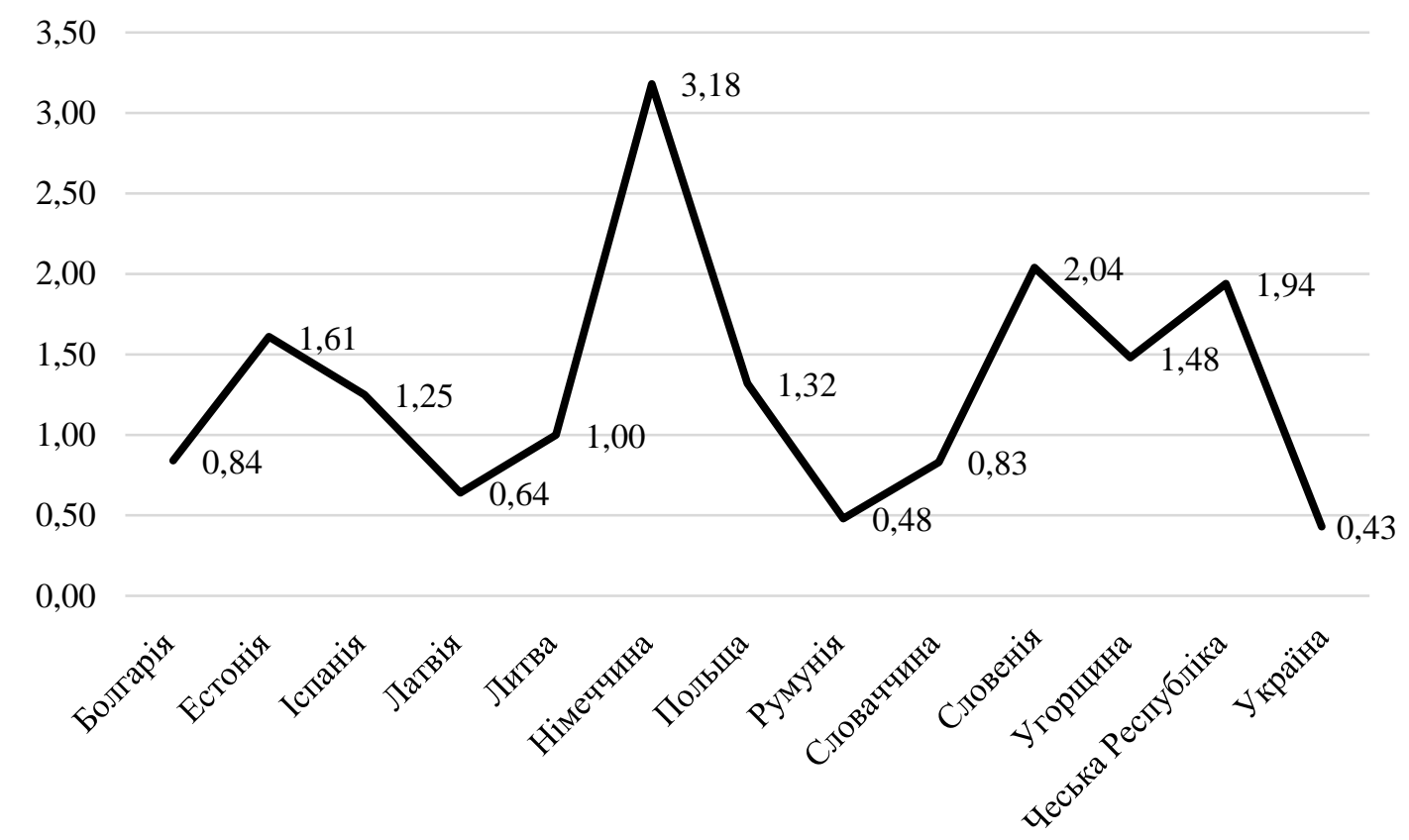

Рисунок 5. Частка витрат на НДР у ВВП, \% [побудовано авторами за даними [4]]

Як бачимо, навіть у країнах-сусідах України частка витрат на НДР у ВВП $\epsilon$ набагато вищою: в Угорщині - 1,48\%, у Польщі - 1,32\%, Словаччині - 0,83\% (проти 0,43\% в Україні), не говорячи про провідні країни Свропейського Союзу.

Основним спонсором інноваційної діяльності в досліджуваних країнах $є$ підприємницький сектор, за винятком Латвії, де переважна більшість витрат на НДР покривається сектором вищої освіти. 
Вітчизняні підприємства, установи, організації сьогодні функціонують у складних і турбулентних умовах, тому часто їхньою метою стає виживання та збереження ринкової ніші та/або конкурентної позиції. Подекуди для цього конче потрібні інновації, провадження яких неможливе без належного забезпечення всіма видами ресурсів i, в першу чергу, людськими та фінансовими.

Також велику важливість мають державна політика, яка має максимально сприяти ефективному стимулюванню до активізації інноваційної діяльності та повсякчасній підтримці інноваційно активних економічних суб’єктів, наявність належної інноваційної інфраструктури та розвиненої інноваційної культури. Тим самим, лише комплексний підхід дасть можливість забезпечити якісні зміни у розвитку інноваційної діяльності в Україні. 